\title{
Designing Model and Strategy for Strengthening The Competitiveness of Small Medium Enterprises
}

\author{
Darwanto', Purbayu Budi Santosa ${ }^{2}$, Nenik Woyanti ${ }^{3}$, Bambang ${ }^{4}$
}

\begin{abstract}
Strengthening the competitiveness of SMEs in Indonesia was essential by the era of global competition in line with the implementation of the ASEAN economic community in 2015. The purpose of this research is designing a model and strategy of strengthening the international competitiveness of SMEs through LEDI - 9F approach. This research is using content analysis and Analytic Networking Process. This research found that the model of strengthening the international competitiveness of SMEs could be done through a model of partnership between the various stakeholders both at district, provincial and state levels. The most priority aspect to strengthen SME's competitiveness is business context with the most priority strategy that is the strategy of management and business. Based on the results of the analysis, the government can use as a reference for the government to strengthen SME's competitiveness through anticipate problems and optimize the solutions that arise in enhancing SME's competitiveness.
\end{abstract}

Keywords: small medium enterprises, local potential, competitiveness, LEDI-9F approach

\begin{abstract}
Abstrak. Penguatan daya saing UMKM di Indonesia dinilai penting seiring dengan era keterbukaan persaingan global dengan berlakunya masyarakat ekonomi ASEAN tahun 2015. Tujuan dari penelitian ini adalah menganalisa model dan strategi penguatan daya saing internasional UMKM dengan potensi ekonomi local berdasarkan pendekatan LEDI - 9F. Penelitian ini menggunakan pendekatan analisis isi dan analytic networking process (ANP). Penelitian ini menemukan bahwa model penguatan daya saing internasional UMKM dapat dilakukan melalui model kemitraan antara berbagai stakeholders baik ditingkat kabupaten, provinsi maupun tingkat pusat. Strategi yang dapat digunakan agar UMKM yang memiliki potensi ekonomi local mempunyai daya saing internasional adalah optimalisasi penerapan teknologi pertanian, strategi manajerial dan bisnis, strategi integrasi vertikal dan horizontal, strategi peningkatan kualitas dan kuantitas produk, strategi pendidikan dan pelatihan tenaga kerja, optimalisasi peran pemerintah dan instansi terkait, pelatihan kewirausahaan bagi UMKM dan calon pengusaha, strategi kemitraan dan pengembangan profesionalitas, dan strategi peningkatan kapasitas.
\end{abstract}

Kata Kunci: usaha kecil dan menengah, potensi lokal, daya saing, pendekatan LEDI-9F

\section{How to Cite:}

Darwanto., Santosa, P.B., Woyanti, N., \& Bambang. (2018). Designing Model and Strategy for Strengthening The Competitiveness of Small Medium Enterprises. Etikonomi: Jurnal Ekonomi. Vol. 17 (1): 69 - 92. doi: http//dx.doi. org/10.15408/etk.v17i1.6826. 


\section{Introduction}

Strengthening the competitiveness of Small and Medium Enterprises (SMEs) is one of achieving the objectives Indonesian nation as mandated in the preamble of Republic Indonesia constitution to promote the social welfare. The urgency of strengthening the competitiveness of SMEs in Indonesia is essential by the era of global competition in line with the implementation of the ASEAN economic community in 2015. It needs to get more attention because of the contribution of SMEs in Indonesia reached 57.5 percent of the national income and be able to employ 17.65 million (Ministry of Cooperative and SMEs, 2015). However, the typical constraints faced by SMEs are: (1), the lack of capital; (2) difficulties in procuring raw materials; (3) lack of access to relevant business information; (4) challenges in marketing and distribution; (5) the low technological capabilities; (6) high transportation costsl (7) the communication problems; (8) problems caused by cumbersome and costly bureaucratic procedures, especially in getting the required licenses; (9) policies and regulations that generate market distortions (Tambunan, 2008).

By Organization for Economic Co-operation and Development (OECD), Sudaryanto (2012) and Vuković et al. (2012) define competitiveness as the ability of firms, industries, regions, or countries to create high and sustain of income and job factors relatively to compete with international competitiveness. Several studies analyzed the competitiveness of SMEs on the factors affecting and the strategy to strengthen its competitiveness. Previous research offered a different determinant of SMEs competitiveness. Differences determinant competitiveness of SMEs indicated that there was no standard for determining the competitiveness of SMEs. Cordeiro and Vieira (2012) defined how research, development, and innovation (RDI) must follow by companies to attain competitiveness. SMEs competitiveness can also be viewed from ownership, education manager, marketing activities, product innovation, and labor (Manole et al., 2014). To make internationally competitiveness, SMEs are influenced by (1) customer relation/ service; (2) technological innovation; (3) corporate strategies (Suh and Kim, 2014; O'Cass and Weerawardena, 2009); (4) international entrepreneurial orientation; (5) key strategic activities (Knight, 2001); (6) adoption of government export programs; (7) details the main implications for managers of small international firms (Hutchinson et al., 2006). Phinaitrup (2011) and Patushi and Kume (2014) suggest cluster development to strengthen the competitiveness of small and medium enterprises with creates horizontal and vertical alliances between entrepreneurs, upstream, midstream, and downstream companies. Hagen et al. (2012) identified different strategic types of internationalized SMEs that were an entrepreneurial/growth-oriented group of firms, a customer-oriented group, a product/inward-oriented cluster, and a further group of firms that lacks strategic orientation. The strategy of strengthening SMEs that offered by Phinaitrup (2011) and Patushi and Kume (2014) was a part of a strategy that provided by Hagen et al. (2012). However, Hagen et al. (2012) research found that only strategic orientation that leads to improved international performance.

To find the determinants and strategies for strengthening the competitiveness of Small and Medium Enterprises (SMEs) are more holistic. One way is to apply the approach to 
LED programs in Indonesia and "Nine Factors" from Cho (Moon and Cho, 2000; Cho and Moon, 2005) simultaneously. The use of these approaches is called to LEDI-9F approach. LED program in Indonesia is a concept of economic development based on empowering local resources available the society (human, natural, and organizational resources) or the process by which the government, private sector, and local communities work together to form better conditions for economic growth and job creation. (Bappeda Jawa Tengah, 2011). Cho (1996) in the Moon and Cho (2000) proposed the concept of international competitiveness based on nine factors. Moon and Cho (2000) and Cho and Moon (2005) offers an application of a general strategy at the enterprise level for a country's competitiveness through cost strategy and differentiation strategy that is strongly influenced by the nine factors of development models diamond porter.

This research is a continuation and development of research of Darwanto (2010 and 2011), Darwanto et al. (2010), and Bambang (2013) on the problems and opportunities facing the SMEs and local economic development. Research Darwanto (2011) describes the strategic role of SMEs in the national economy. Darwanto (2010) stated that SMEs used more employment than big industry. But, high labor absorption not followed by the ability to produce. It indicates that SMEs has low efficiency and competitiveness. Darwanto (2010) stated that need a partnership based on the principle of synergy that is a mutual need and mutual help in developing SMEs. Bambang (2013) noted that program of Local Economic Development (LED) could improve SME's empowerment through a business cluster approach.

Here, the purpose of this study is to analyze models and strategies of strengthening the international competitiveness based on Local Economic Development in Indonesia Nine Factors (LEDI-9F) Approach. Model of enhancing SME's competitiveness based on a program of Local Economic Development in Indonesia that has applied in Central Java Province. Program of LED in Indonesia has advantages in the aspects of comprehensiveness both at the policy level and technical level. To complete the model of strengthening the competitiveness of SMEs, this research will develop strategies based on the various aspects of the problems faced by SMEs through international competitiveness approach that called with nine factors model. The Nine-Factor model includes workers, politicians and bureaucrats, entrepreneurs, professionals, factor conditions, demand conditions, related and supporting industries, business context, and chance event. (Moon and Cho, 2000; Cho and Moon, 2005). This study also took SMEs and regions that have local potential as a research object.

\section{Method}

The research conduct in Province of Central Java which is a regional pilot program Local Economic Development (LED) in Indonesia. Local Economic Development (LED) is defined as the growing local economy to improve the welfare of residents (Bartik, 2004). LED also can be described as a process that puts local government or communitybased organizations to manage local resources and make partnerships with the private 
sector to create new jobs and stimulate economic activity in the region (RodriguezPose and Tjimstra, 2005; Blakely, 1994; Canzanelli, 2001). LED's roadmap has five repeating cycle stages. According to Bambang (2013), the fifth stage of the roadmap can be described as follow: First, preparing and strengthening the institutional platform of LED. The institution of the LED in the city and county conduct by utilizing and optimizing the existing institutional system that is Forum for Economic Development and Employment Promotion (FEDEP) that have run in each city and region. At this stage, the FEDEP platform can be evaluated and re-mapping, to strengthen the existing institutional including institutional forum (composition, performance, work program), stakeholders completeness members forum supported by the mechanism of dialogue and the formulation of an agreement for Local Economic Development (LED) and supportive policies. FEDEP consists of the institutions that serve to execute the activities \{regional government institution, a group of business actors, business support groups, Business Development Services (BDS)\}.

Second, mapping and analyzing the condition of LED which is intended to identify the potential area of the LED, the supporting factors, and the strategic environment needed as a lever for cluster development and excellent products. The analysis of local potency conducts as an attempt to identify and determine the superior product. The main criteria to determine the superior product is a product that has a great value added and a multiplier extensive local business, as well as competitive in domestic business and international business. There is value chain analysis of the production process of each product business, to get information about multiplier effect and business value-added from every local product.

Third, the preparations of the action plan for the LED, the business plan, and internalization to the local budgets. The action plan is needed for the development of the LED at the municipal/district level, preparation for business plans for a cluster, as well as synchronization and adoption of the regional program of local government budgeting for the LED. The focus of the action plan and the LED budgeting is aimed to support cluster development and superior product that has been agreed on the activities of the LED at the second phase.

The fourth phase is the implementation of the LED program conducted by the stakeholders as a member of FEDEP following the action plan, and the budget that has been prepared before. The cluster business conducts the business plan supported by some actors like Cluster Consultation Forum (CSF), business development services, cooperatives, and the other supporting units of cluster business. Cluster consultation forum is a dialogue medium to set an agreement to carry out the Business Plan. Business Development Services (BDS) has a role as business manager and cluster facilitators which conducting business and non-business supervision. Cluster or BDS manager stay at the cluster management office, located in the business environment, coordinated by FEDEP. Cooperative is the business device of CSF.

The fifth phase is monitoring, evaluating, and improving LED program. The monitoring 
activity is conducted to monitor the LED that has been conduct by local government. The evaluation activity of the LED is intended to assess the performance of the LED implementation, as well as supporting device to formulate a program improvement and strengthening of program implementers' methods of the LED. In conducting the evaluation, the evaluation instrument needed. In this model, the variable of growth and distribution as the criteria for the outcome of the LED should be included as it is associated with the target of the regional development plan.

In particular, the objects of this research are the SMEs in Banyumas, Wonosobo and Banjarnegara District, Province of Central Java. SMEs in these regions have the potential of local economies that have characteristics of high locality and faced with increasingly competitive market competition. The local potential that owned by SMEs in the regions is the product of carica and coconut sugar. These products have export to many countries.

Method of analysis in this research used content analysis and Analytic Networking Process (ANP). Content analysis was used to develop a model of the strengthening SME's international competitiveness. Analytic Networking Process (ANP) as a model to determine the strategy of strengthening the international competitiveness of SMEs. According to Ascarya (2009), this study applied ANP method in three steps. First, questionnaires and in-depth interviews with actors of Small and Medium Enterprises, Regional Development Planning Board, Department of SMEs and Cooperative, scholar, expert, and Non-Government Organization (NGO) are conducted to comprehend the real problems to strengthen SME's competitiveness fully. Respondents of questionnaires and in-depth interviews totaled 15 people that consist of 7 scholars, five business actors, $6 \mathrm{NGO}$, and six governments. Second, the results of the preliminary stage are used to develop an appropriate ANP network and relevant questionnaires to glean the necessary data from experts and practitioners of SME. Third, ANP analysis is applied to set priority alternative solutions and policy strategies to formulate optimal policy recommendations. Problems Identification, alternative solutions and policy strategies in this research based on Nine Factors model from Cho and Moon (2005).

\section{Result and Discussion}

\section{Model of Strengthening SME's Competitiveness}

Strengthening the competitiveness of SMEs in Indonesia is integrated and sustainable either from the central, provincial, and district / city. Central government became the prime mover program to strengthen the SME's competitiveness, while the provincial and district government is a representative of a central government, which acts as the technical accompanying SMEs directly. Model of strengthening the SME's competitiveness, especially SMEs that have a potential local economy, does not only depend on the role of government alone, but also should involve various stakeholders such as business associations, academics, NGOs and SMEs themselves. Model of strengthening the competitiveness of SMEs can be seen graphically in Figure 1. 
Figure 1. Model of Strengthening SME's Competitiveness

State Level

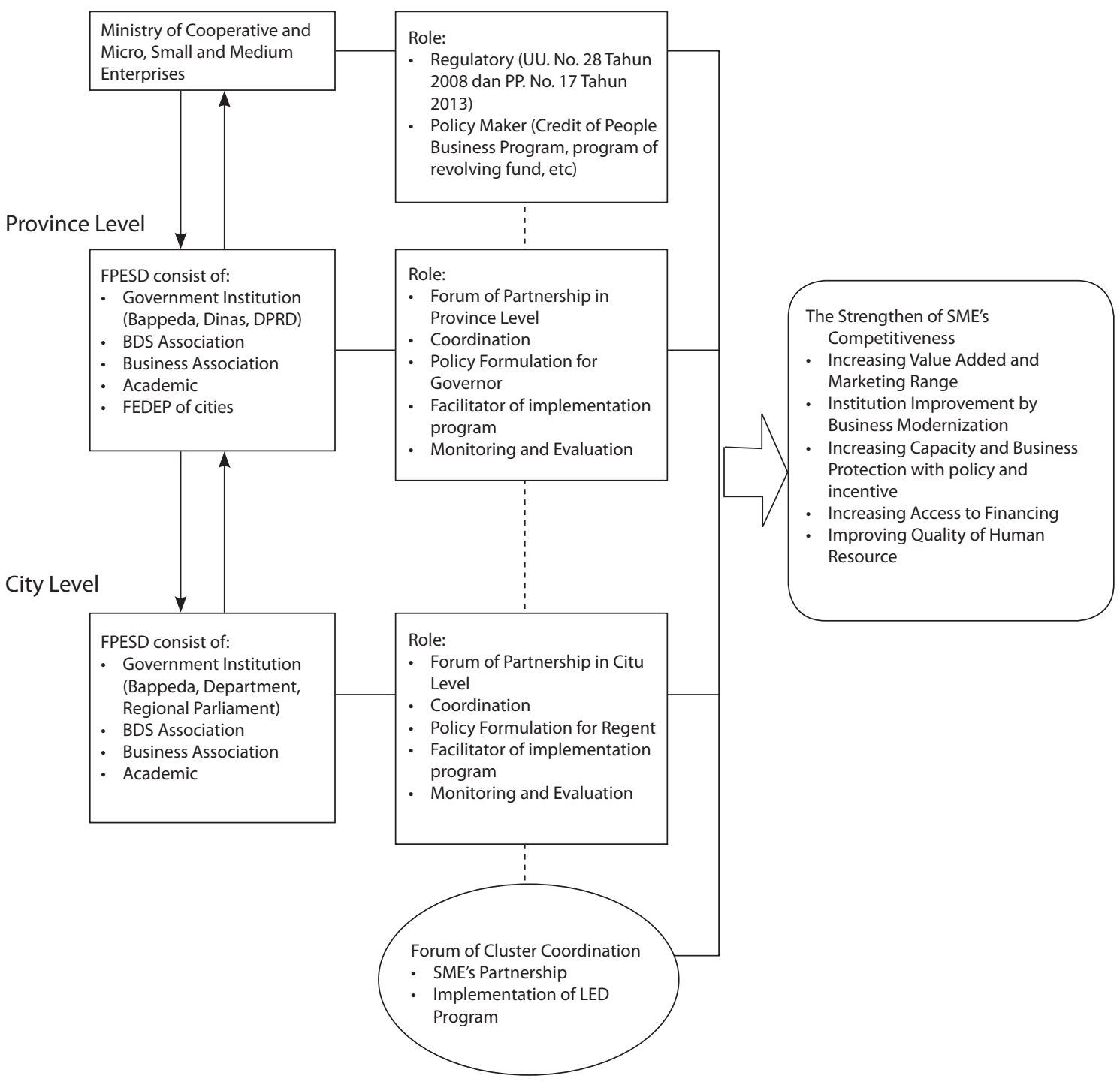

The central government's role that represented by the Ministry of Cooperatives and SMEs is regulators and policymakers. The role of the central government as the regulator can be seen in the legislation and legal products that have been made. The legislation and legal products to strengthen SME's competitiveness are included The Act No. 28 of 2008 and The Government Regulation No. 17 of 2013. The Act No. 28 of 2008 regulates the micro, small and medium enterprises in which the SME's empowerment is an integral part of the national economic development. SME's empowerment conducted as holistic, optimal, and sustainable through developing a conducive to business climate, opening business opportunities, supporting, protecting, and developing business widely. The goal of its empowerment is improving the position, role, and potential of SMEs in achieving economic growth, equity and improvement of people income, job creation, and poverty reduction.

Also, to act as a regulator, the central government also has a role as a policymaker through the government programs that support the increasing competitiveness of SMEs. Some of the 
main program of the central government to SME includes People's Business Credit (PBC), program of a revolving fund, SME's Entrepreneurial Development, Tax Amnesty and others. In the way to strengthen the competitiveness of SMEs, the central government also has a work plan that interacted directly with improving the quality of SMEs through increased understanding and application of quality management standardization, Intellectual Property Rights (IPR), and halal products. The central government also provides guidance and consulting utilization of e-commerce and application system business, vocational training, and offer Business Skills Practice Sites (BSPS).

The provincial government is an institution that interacted directly with the program to strengthen the competitiveness of SMEs, to optimize the central government program that has made. In Central Java, a program to enhance SME's competitiveness can be done through Local Economic Development (LED) program. Forum of Economic Development and Resources (FEDR) and Forum coordinate local Economic Development (LED) program for Economic Development and Employment Promotion (FEDEP). FEDR and FEDEP task is to assist the regent in developing policy formulation, facilitation of implementation, monitoring and evaluation of regional development policies, primarily related to the empowerment of SMEs. The purpose of the establishment of FEDEP and FEDR is to accelerate the program of Local Economic Development (LED) based on sustainable clusters business.

Figure 1 also shows the linkages between institutions of Local Economic Development (LED) forum in Central Java. As the institution at the provincial level, at least FEDR membership consists of regional department, parliament, chamber of commerce, business associations, universities, representatives of SMEs (business cluster), Association of Business Development Services (BDS), and FEDEP regency / city (for members FEDR). As institution at the district / city level, FEDEP members consist of several components like business associations, large enterprises, regency / city and public departments, and BDS. To perform activities related to Local Economic Development (LED), FEDR obtains funding from provincial budgets and other assistance (central government or donors), while FEDEP obtains funding from the budget of the district / municipal, provincial aid and other assistance.

Besides FEDR and FEDEP, Forum of Consultation Cluster (FCC) is an institutional unit as the smallest production business areas in each district/ city. Forum of Consultation Cluster (FCC) consists of a group of SMEs are supported by the related departments/ agencies. Cluster in the district/ city is the prime mover of the economy and the core of the program Local Economic Development (LED) in Central Java. The purpose of this cluster development is expected to boost the economy of local communities that support the development goals in Central Java that are pro-poor, pro-jobs and pro-growth. Cluster in Central Java is grouped into three categories: beginners, developing and developed. Number of clusters in Central Java as part of the Local Economic Development (LED) is 185 cluster. This cluster consisting of 43 agriculture cluster (37 beginners category and six developing categories), 122 industrial clusters (71 beginner category, 50 of developing category and one developed category), and ten tourism clusters ( 6 beginners category and four developing categories). 
Forums of Local Economic Development (LED) institutions, either FEDR, FEDEP or Forum of Consultation Cluster (FCC), are the executor and the guardian of the implementation of Local Economic Development (LED) program. In general, stakeholders realize the roadmap of Local Economic Development (LED) program in the stages of implementation activities that guarded jointly. These stages consist of preparing and strengthening the platform of institutional (FEDEP), mapping and analyzing the LED condition, developing an action plan of LED, developing business plan and internalization into the local budget, implementing Local Economic Development (LED) program, and monitoring, evaluating, and improving LED program.

Coordination and synchronization of the central, provincial and district/ city level can do through program preparation and authority division. Through optimization of the role that has done at all levels, the expected output is the strengthening the competitiveness of SMEs in Indonesia. An indicator of its strengthening competitiveness can be looked through increasing value-added and marketing range, improving institution by business modernization, increasing capacity and business protection with policy and incentive, increasing access into financing, and improving quality of human resource.

\section{Strategy for Strengthening SME's Competitiveness}

To make a design of the procedure for strengthening theSME's competitiveness, this research uses Analytic Network Process (ANP) method, which consists of some steps. The steps are decomposition, pairwise comparison, and synthesis and analyze. The decomposition step determined the aspects in the strengthening SME's competitiveness, problem identification, construct alternative solutions and strategies. Based on the identification of problems, alternative solutions, and strategies to strengthen SME's competitiveness in the decomposition step, Analytic Network Process (ANP) framework divided into two sections. The first section consists of hierarchy and sub-criteria that controls interaction. The second section is network effect between elements and clusters. The feedback network that used in this research and the result of steps from ANP method shows in Appendix.

Figure 2. Aspect Priority of Strengthening SME's Competitiveness

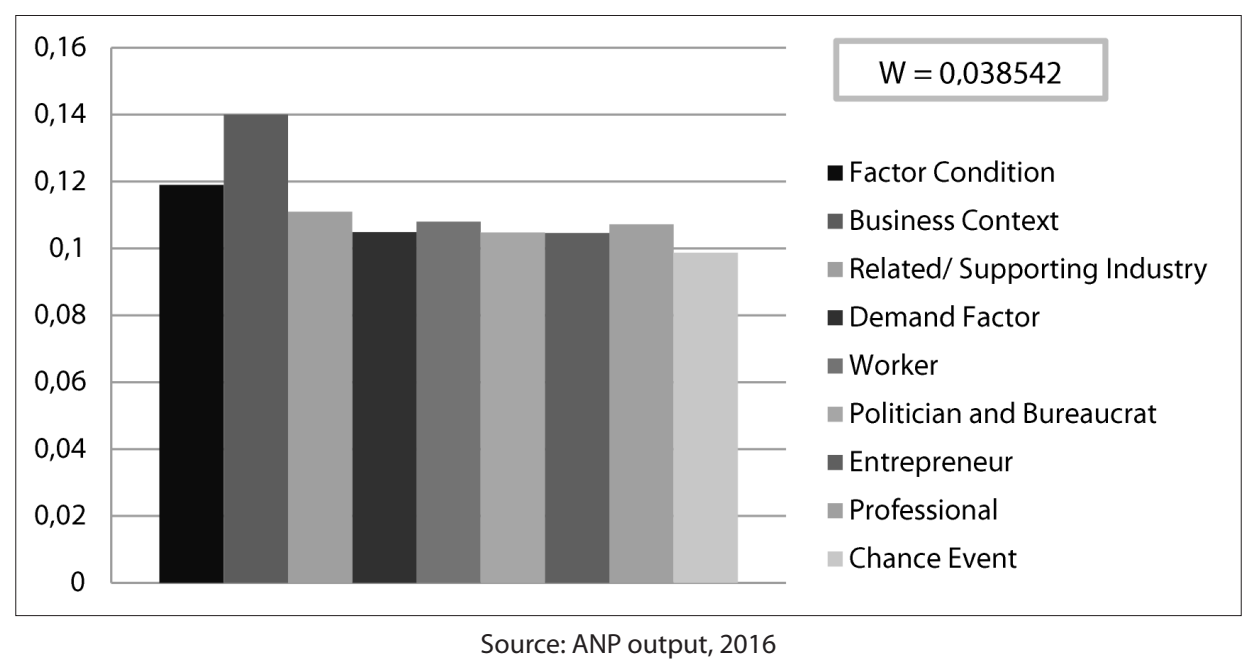


Based on an in-depth interview with experts and practitioners of SME, the discussion of Analytic Network Process (ANP) include aspects discussion, problems and alternative solutions of each aspect, and priority strategies that resulted by ANP model. Elements were observed to design a plan of strengthening SME's competitiveness refer to competitive criteria from Cho that called with "Nine Factors" model. Cho and Moon (2005) state that "Nine-Factors" model consisting of factor conditions, demand conditions, related and supporting industries, business context, workers, politicians and bureaucrats, entrepreneurs, professionals, and chance event. The results of aspect priority in the strengthening SME's competitiveness can be seen in Figure 2.

Figure 3. Problem Priority of Factor Conditions

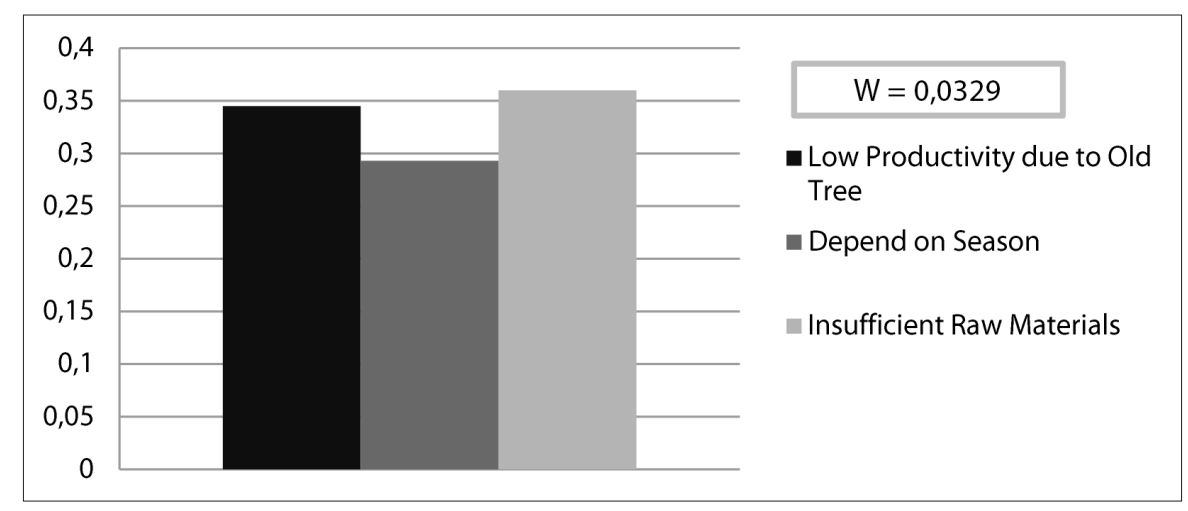

Source: ANP output, 2016

The results of the priority aspects based on 24 respondents indicated that the most important to strengthen the SME's competitiveness was an aspect of the business context. The second important an aspect was aspect of factor condition. The third aspect was related/supporting industry. The fourth aspect was labor. The fifth aspect was managers and professionals. The sixth aspect was politicians and bureaucracy. The seventh aspect was domestic demand. The eighth aspect was an entrepreneur. The ninth element was events and opportunities. All of the priority aspects had rater agreement value $\mathrm{W}=0.0385$.

Figure 4. Solutions Priority for Aspect of Factor Conditions

\begin{tabular}{|c|c|}
\hline 0,36 & $W=0,0017$ \\
\hline 0,35 & \\
\hline 0,34 & -The Rejuvenation of Trees \\
\hline 0,33 & and Genetic Engineering \\
\hline 0,32 & Expansion of Crop Land \\
\hline 0,31 & for Raw Materials \\
\hline $\begin{array}{r}0,3 \\
0,9\end{array}$ & \\
\hline 0,28 & \\
\hline
\end{tabular}

Source: ANP output, 2016 
After knowing the most crucial aspect in strengthening the competitiveness of SMEs, the next analysis step is analyzing the problems and solutions of each element. The elements include factor conditions, demand conditions, related and supporting industries, business context, workers, politicians and bureaucrats, entrepreneurs, professionals, and chance event. The results of in-depth interviews indicated that the problems of factor conditions in strengthening the competitiveness of SMEs included low productivity due to the old tree, depending on the season, and insufficient raw materials. Priority problems in the condition factor aspect shown in Figure 3. Based on factor condition, the results of the interview from 24 respondents indicated that the crucial issue was insufficient raw materials. The second concern was low productivity due to the old tree, and the last was a problem of depending on the season. The value of rater agreement for condition factor is equal to $\mathrm{W}=0.0329$.

Figure 5. Problem Priority of Business Context Aspect

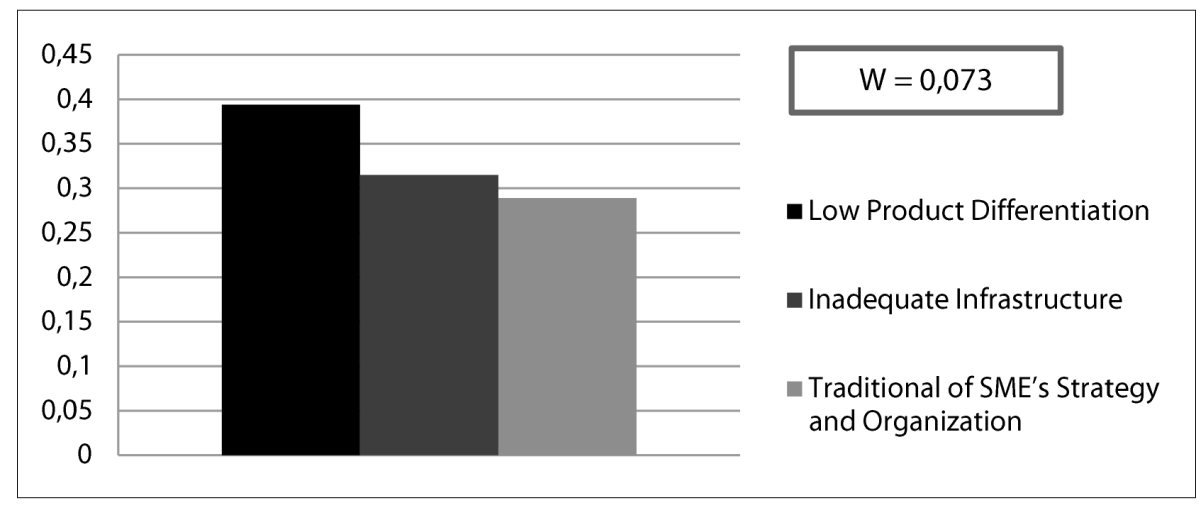

Source: ANP output, 2016

The solutions offered based on the problems are the trees rejuvenation and genetic engineering, expansion of cropland for raw materials, and grants of seeds. Figure 4 shows that the top priority solution from the aspect of factor condition based on the respondent interview was the rejuvenation of trees and genetic engineering. The next priority was the expansion of cropland for raw materials, and grants of seeds. Solutions aspects of factor condition had rater agreement value of $\mathrm{W}=0.0017$.

According to NIKRAFTAR (2016), the factor conditions have a substantial impact on the industrial competitiveness of SMEs especially the stone industry. Also, the demand conditions variable, related and supporting industries variable, and firm strategy, structure, and rivalry variable have a positive impact on competitiveness. Factor conditions can be: 1) availability of raw materials; 2) quality of raw material; 3) employees' costs; 4) employees' capabilities;5) new scientific and technical information about products and services; 6) availability of new technologies; dan 7) availability of financial resources.

For the problems of the business context aspect, results of in-depth interviews indicate that the issues faced were low product differentiation, inadequate infrastructure, and traditional of SME's strategy and organization. The results of the analysis in Figure 5 showed that the critical problem according to respondents was low product differentiation. The 
second priority was inadequate infrastructure facilities, and the last was traditional strategy and organization of SMEs. The rater agreement value of problem aspect in the business context was $\mathrm{W}=0073$.

Figure 6. Solutions Priority for Aspect of Business Context

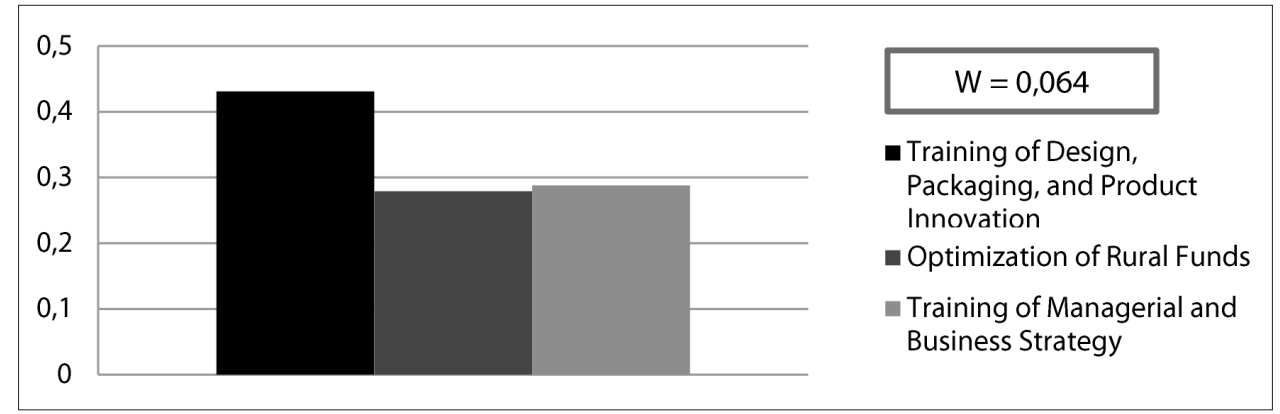

Source: ANP output, 2016

The solution offered based on the problem are the training of design, packaging, and product innovation, optimization of rural funds, and training of managerial and business strategy. Figure 6 shows that the solution priority of the business context of the business according to the respondents. The main priority was the training of design, packaging, and product innovation. The second priority was the training of managerial and business strategy. The last was the training of design, packaging, and product innovation, optimization. Solutions in the business context had rater agreement value of $\mathrm{W}=0.064$.

Figure 7. Problems Priority of Related and Supporting Industry

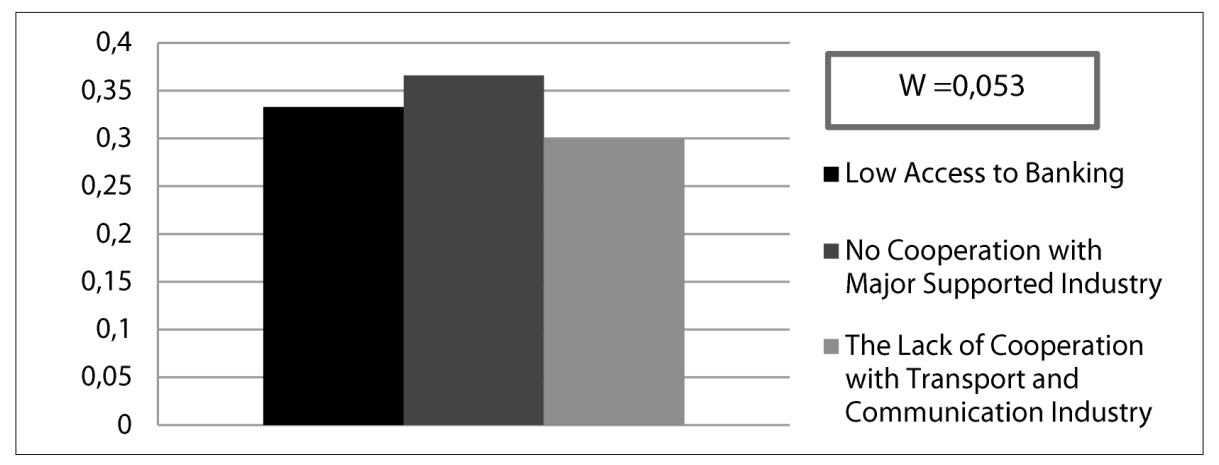

Source: ANP output, 2016

The result of business context aspect is similar to Anton et al. (2015), who found that the competitiveness of SMEs in Indonesia was affected by business performance (level of education, working capital, level of innovation and business strategy). Each variable significantly has a positive effect on business performance. Also, SMEs should strengthen the level of innovation by creating product innovation (design, raw materials, etc.), creating a new promotional mix, exploring new buyer and supplier, exploring new distribution networks and developing new products. 
Problems of related/ supporting industry in this study included low access to banking, no cooperation with major supported industry, and the lack of collaboration with the transport and communication industry. The results of the analysis in Figure 7 showed that generate a priority issue in the related/ supporting industry aspects was no cooperation with major supported industry. Besides of the main problem, low access to banking and lack of collaboration with the transport and communication industry became the second and third priority. Issues in the related/ supporting industries aspects had rater agreement value of $\mathrm{W}=0.053$.

Figure 8. Solutions Priority for Aspect of Related and Supporting Industry

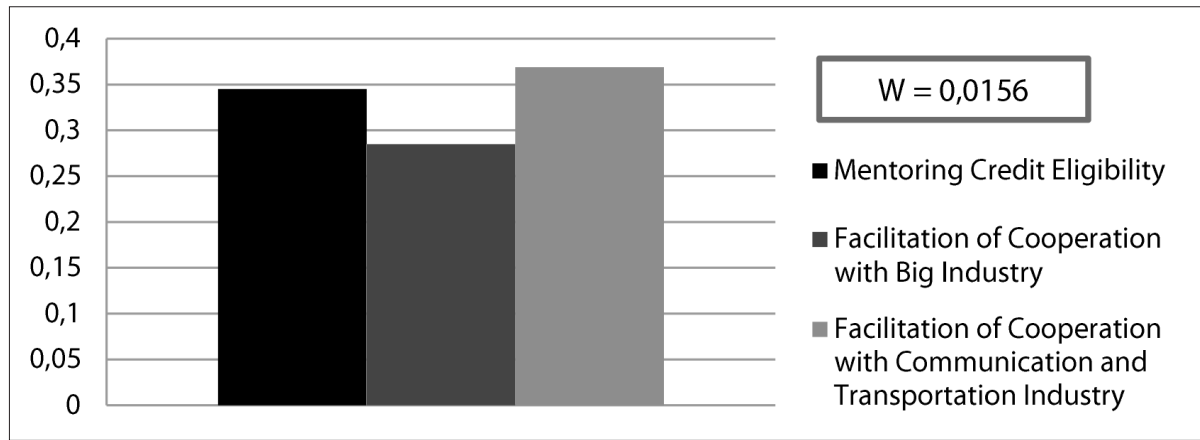

Source: ANP output, 2016

The solutions based on the problems priority are mentoring credit eligibility, facilitation of cooperation with big industry, and facilitation of cooperation with communication and transportation industry. Figure 8 shows that the solution in the aspects of related/ supporting industry accordance with the respondent opinion that has first priority was the facilitation of cooperation with communications and transportation industries. The next priority was mentoring credit eligibility and facilitating collaboration with large industry. Solutions in the aspects of related/supporting industry had rater agreement value of $(\mathrm{W}=0.0156)$. According to Maciej and Natalia (2016), the companies/ small, medium-sized enterprises (especially in Poland) that open to cooperation with customers and academic institutions of the Polish Academy of Sciences (PAN) and the companies are members of clusters have a positive impact such as having chance to create large-scale innovations in the area of innovative activities.

Figure 9. Problems Priority of Demand Factor

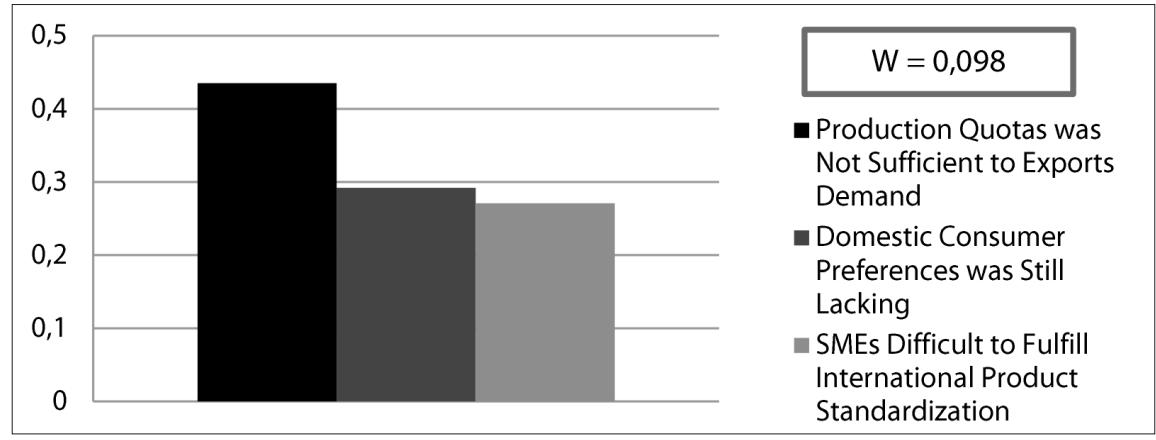

Source: ANP output, 2016 
The problems priority of demand factor which consisted of production quotas was not sufficient to exports demand, domestic consumer preferences were still lacking, and SMEs difficult to fulfill international product standardization. Figure 9 showed that the main problem in the demand factor aspect that was production quotas not sufficient to exports demand. The second was consumer preferences in the country still lacking, and the last was SMEs difficult to fulfill international standards. Problems in the demand factor aspect had rater agreement value $\mathrm{W}=0.098$.

Figure 10. Solutions Priority for Aspect of Demand Factor

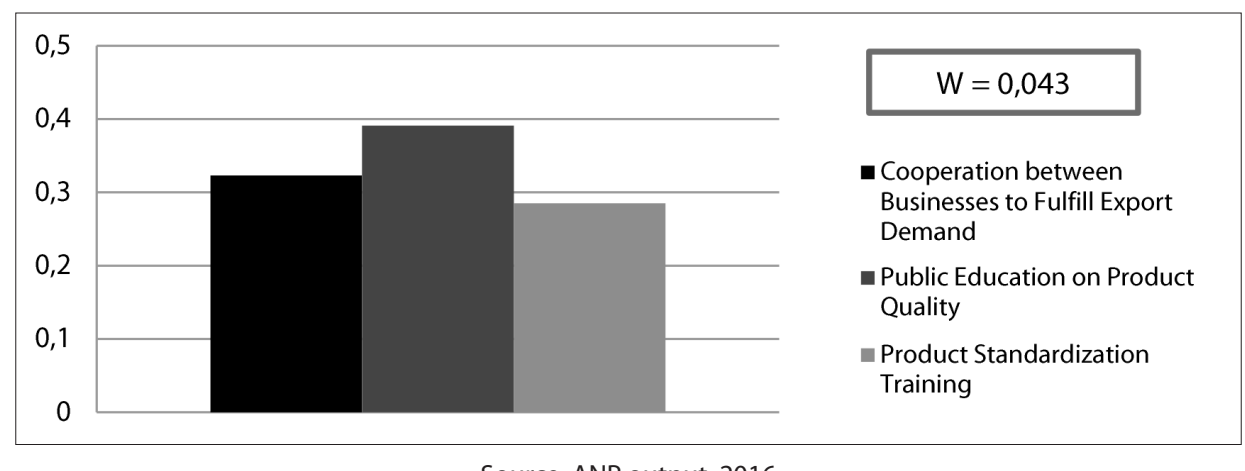

Source: ANP output, 2016

The results of in-depth interviews with 24 respondents indicated that the solutions related to aspects of demand factors included cooperation between businesses to fulfill export demand, public education on product quality, and product standardization training. Figure 10 shows the solution from the aspect of domestic demand according to respondent's perception. The main priority was educating the public on the product quality. The second priority was cooperation between businesses to fulfill export demand. The third was training product standardization. Solutions in the aspects of domestic demand had rater agreement value of $\mathrm{W}=0.043$. According to NIKRAFTAR (2016), demand conditions have a positive and significant impact on competitiveness. Demand conditions are important but the effect is not stronger than factor conditions. Demand conditions include: 1) domestic consumer knowledge and information about the products; 2) neighbouring countries' share in foreign demand; 3) size of domestic demands; 4) impact level of cultural diversity on products; and 5) structure of domestic demand.

Figure 11. Problems Priority of Worker

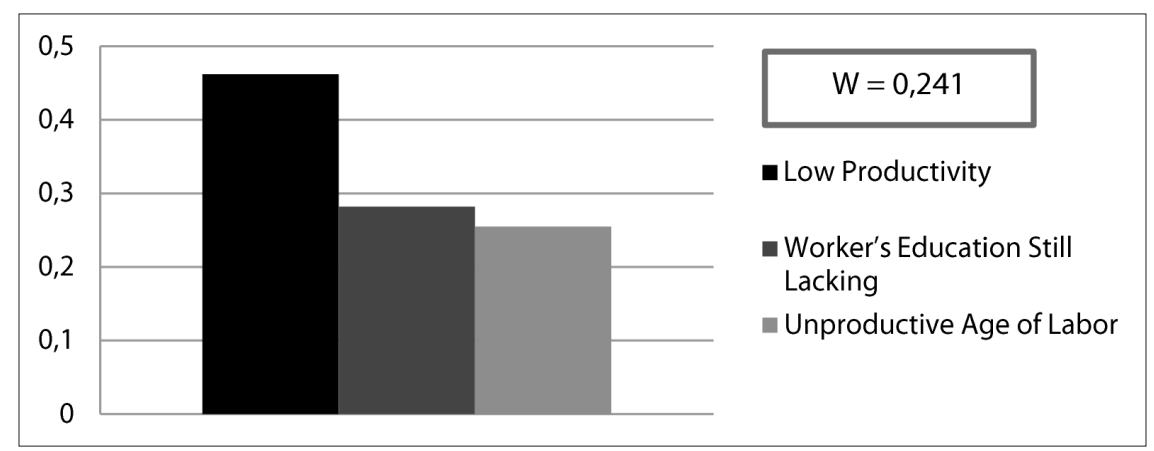

Source: ANP output, 2016 
The result of an in-depth interview with 24 respondents on labor aspect is shown in Figure 11. The first priority in the labor aspect according to the respondents was low productivity. The second priority was worker's education still lacking and the last was the unproductive age of labor. Problems in the labor aspect had rater agreement value of $\mathrm{W}=0.241$.

Related solutions to the problems faced in the worker aspect included acceleration of adopting new technologies, education and training for workers, and regeneration of the workforce through vocational education. The result of ANP data processing in Figure 12 shows that the solution from the aspect of labor based on a respondent interview that has first priority was the acceleration of adopting new technologies. The next priority was education and training for workers. The last was a regeneration of the workforce through vocational education. A solution of worker aspects had rater agreement value of $\mathrm{W}=0.105$. According to Ngatno, et. al.. (2016), human capital and entrepreneurial capital have a positive impact on competitive advantage but they do not have a direct impact on SME's performance.

Figure 12. Solutions Priority of Worker Aspect

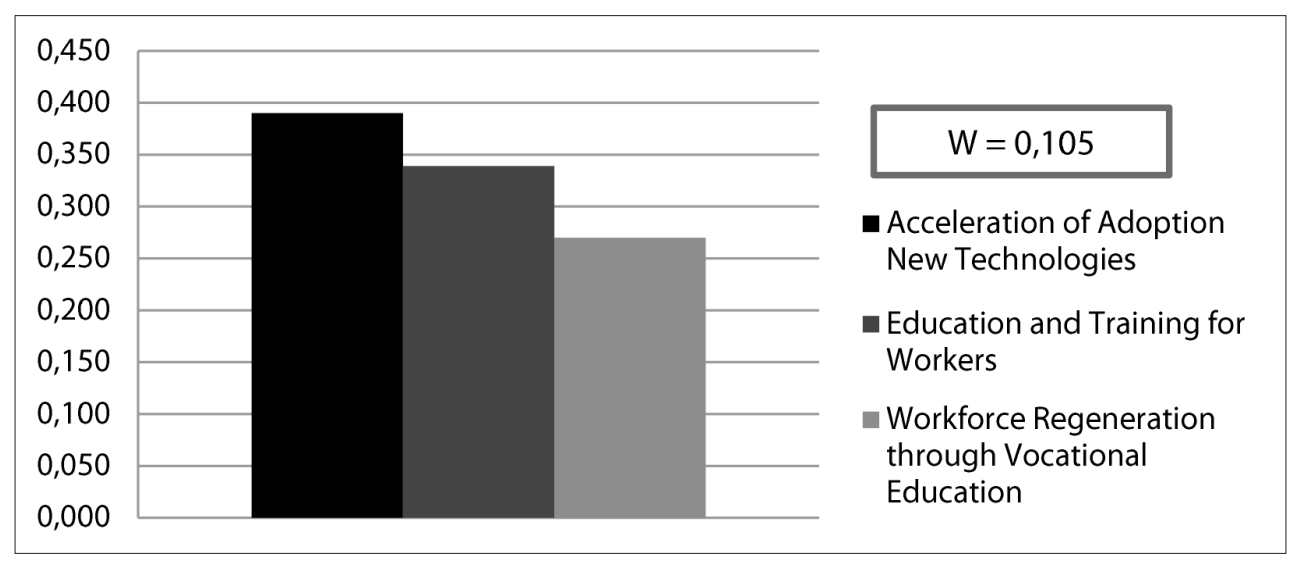

Source: ANP output, 2016

Problems in the politicians and bureaucratic aspect included the lack of budgetary support, unoptimal implementation of the regulation, and the lack of coordination between departments. The main problem in the aspect of politician and bureaucracy was not the optimal implementation of the regulation. According to Quartey (2001), the regulations implementation on SMEs especially SMEs in developing countries aimed to decrease negative impact on SMEs. Regulation may stimulate productivity forms of competition especially SMEs productivity and it affects growth depend on the direction change. Besides that, the lack of budgetary support and coordination between departments became another problem in the aspect of politicians and bureaucracy. Problems politicians and bureaucratic aspects had rater agreement value of W $=0.0156$ (See Figure 13). 
Figure 13. Problems Priority of Politician/ Bureaucrat Aspect

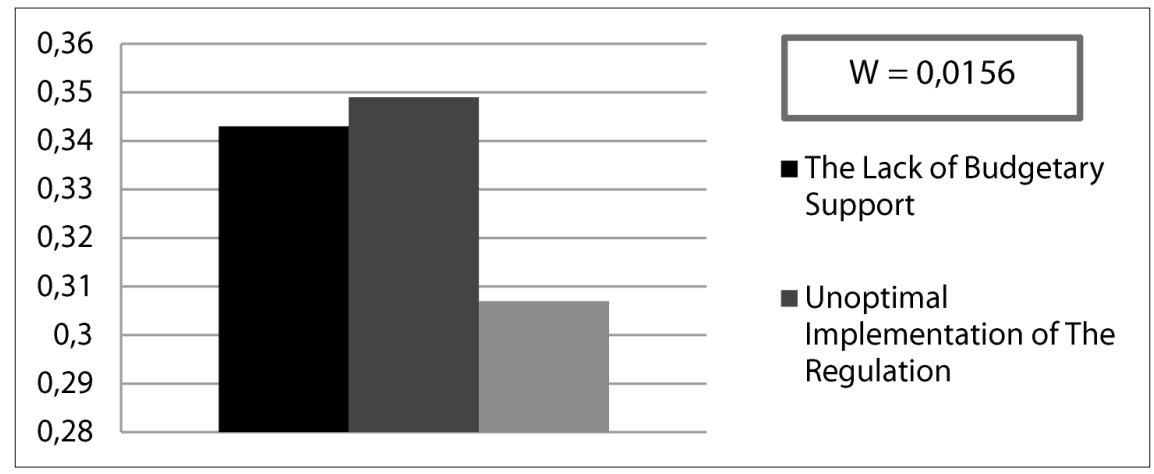

Source: ANP output, 2016

The solutions problem in the aspect of politicians and bureaucratic accordance to the perception of respondents included the budget optimization through priority scale, optimization of the regulation implementation, and increasing intensity of communication between departments. Figure 14 shows that the solution in the aspect of political and bureaucratic according to the respondents. The main priority was the budget optimization through priority scale. The second priority was the increasing intensity of communication between departments. The third was optimization of regulation implementation. Solutions in the aspect of politicians and bureaucratic had rater agreement value $\mathrm{W}=0.048$.

Figure 14. Solutions Priority for Aspect of Politician and Bureaucrat

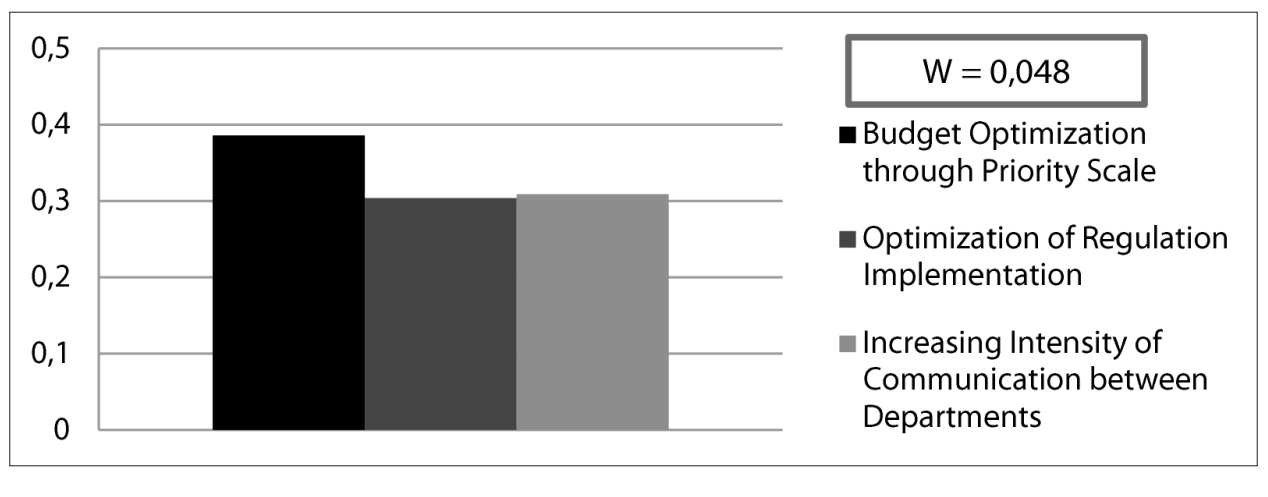

Source: ANP output, 2016

Problems in the entrepreneur aspect included less innovating SMEs, few of young entrepreneurs, and no much support for new businesses. Figure 15 shows that the main priority problem in the entrepreneur aspect was less innovating SMEs. In addition, few of young entrepreneurs and not much support for new businesses became the other problems in the entrepreneur aspect. Problems in the entrepreneur aspects have rater agreement value of $\mathrm{W}=0109$. 
Figure 15. Problems Priority of Entrepreneur Aspect

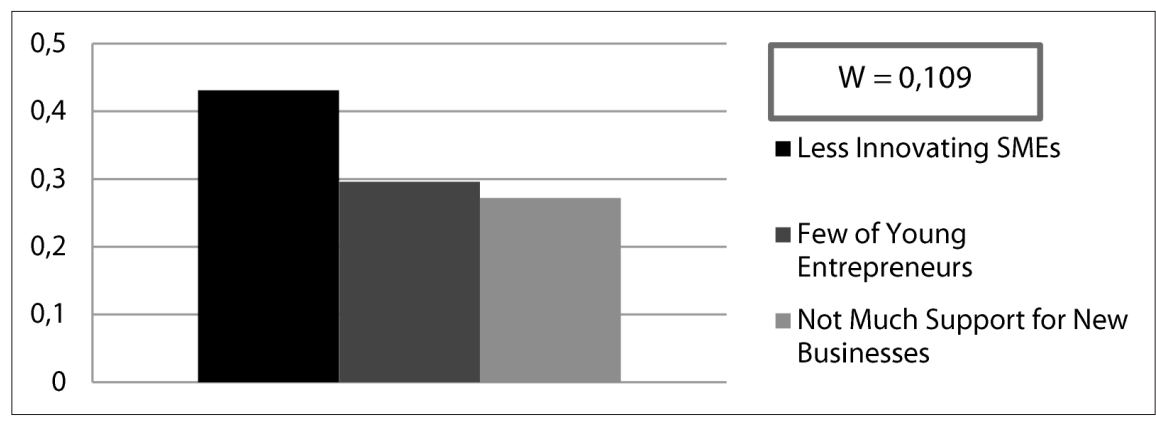

Source: ANP output, 2016

Related to aspects of the entrepreneur, the respondent's perception through in-depth interviews indicated that the solution for problems in the aspect of entrepreneur included entrepreneurial training and mentoring, a business incubator, and grants for young entrepreneurs. Solution based on the entrepreneurial aspect of the respondent's interview that had top priority was entrepreneurship training and mentoring. The next priority was a business incubator, then grants for the young entrepreneur. Solutions in the aspect of entrepreneur had rater agreement value of W = 0.192 (See Figure 16). According to Sánchez (2012), entrepreneurial competencies have not only direct effect, but also an indirect effect on SMEs especially firm performance by mediating effect of organizational capabilities. Entrepreneurial competence plays an influential role in organisational capability and competitive scope. Lazar and Paul in Mahadalle and Kaplan (2017) explain that the entrepreneurial competencies has a positive impact on the firm performances and the competitiveness. Some of the entrepreneur competencies such as lifestyle improvement, expansion of the business facility, adoption of better technology and problemsolving capability. Beside the entrepreneurial competencies, the entrepreneurial characteristic is the determinant of business performances in small and medium enterprises. The entrepreneurial characteristic such as education, value of personal, experience in work, a support network of professional, psychological factors and attributes (Mahadalle \& Kaplan, 2017).

Figure 16. Solutions Priority for Aspect of Entrepreneur

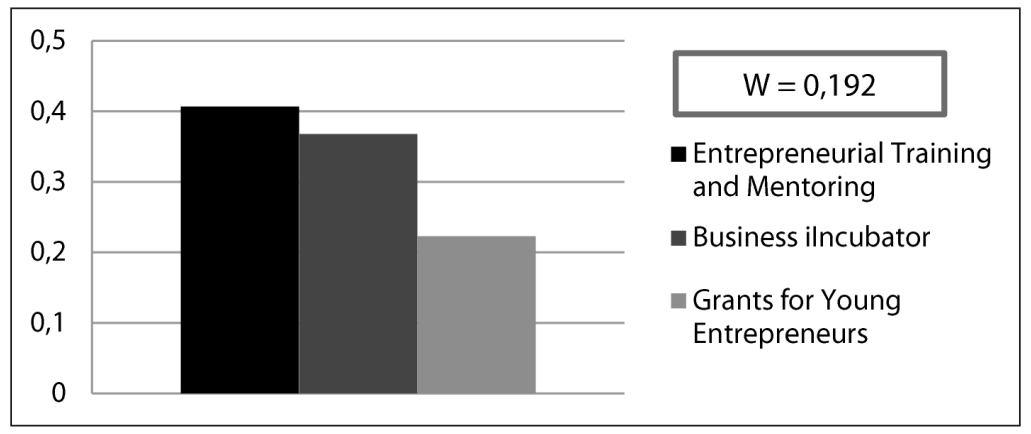

Source: ANP output, 2016

Problems in the professional aspect include unprofessional management system, lack of partnerships with business professionals, and owner doubles as manager. Figure 17 shows that 
the top priority problem of professional aspect was yet professional management system. It was accordance with the opinion of the respondents. The second priority was the owners' act as a manager, and the last priority was partnerships with business professionals still lacking. Problems aspects of professionals had rater agreement value of $\mathrm{W}=0.074$. According to Kraja and Osmani (2013), some SMEs especially in Albanian faced the problems that made SMEs are not able to maintain the competitive advantage. The problems are poor management, lack of managerial education, lack of initiative, lack of vision and mission, lack of investment, lack of experience, lack of marketing research, and etc.

Figure 17. Problems Priority of Professional Aspect

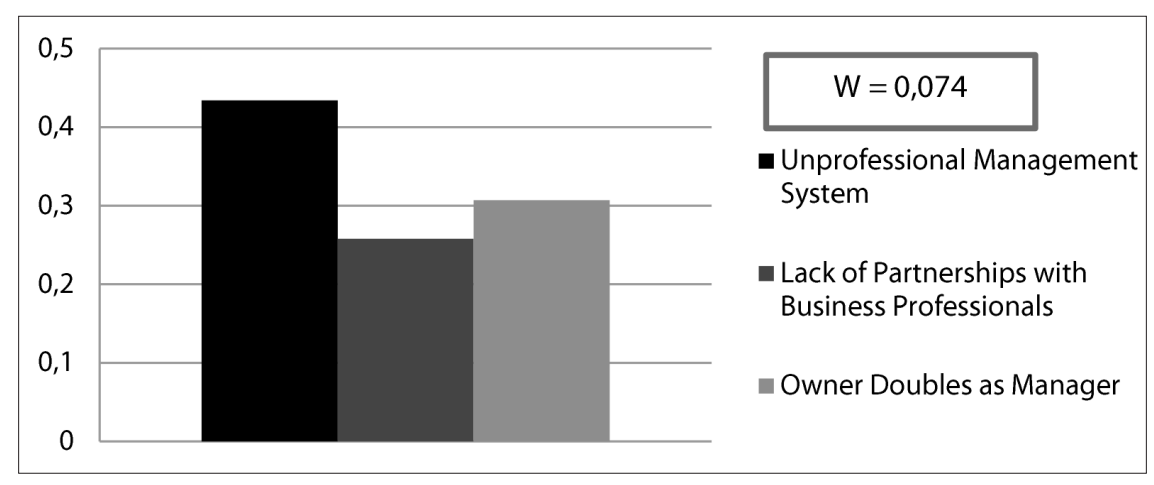

Source: ANP output, 2016

Solutions that can be offered to solve the problem on the professional aspects included training of managerial and organizational systems, facilitating a partnership with the business professional, and the tasks division towards professionals business. Figure 18 shows the solution from the aspect of professionals. According to respondents, the main priority was the facilitation of partnership with business professionals. The second priority was the training of managerial and organizational systems and the third was tasks division towards business professionals. Solutions in the professional aspects had rater agreement value $\mathrm{W}=0.083$.

Figure 18. Solutions Priority for Aspect of Professional

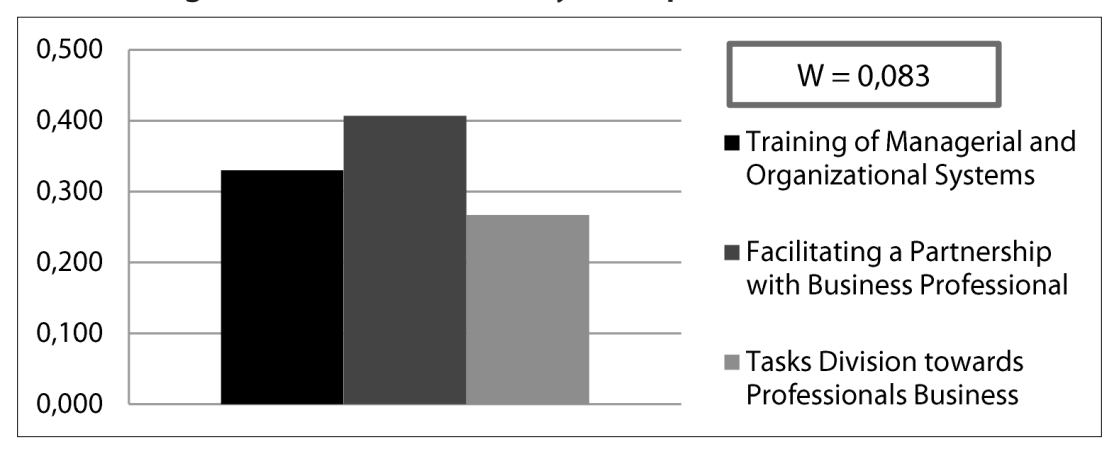

Source: ANP output, 2016

Problems in the chance event aspect include unable to capture the opportunities of information technology development, high costs to follow the event/ exhibit, and unable 
to optimize the opportunities. Figure 19 shows that the main priority in the chance event aspect problems based on the respondents was unable to capture the opportunities of information technology development. According to Kossai and Piget (2014), information and communication technology is associated with better performance of SMEs especially Tunisian manufacturing SMEs. The SMES (Tunisian SMEs operating in the electrical and electronic industry) applied information and communication technology and the SMEs do not apply information and communication technology has the different levels of net profit margin. The second problem priority was high costs to follow the event promotion, and the last priority was unable to optimize the opportunities that exist. Problems in the chance events aspect had rater agreement value of $\mathrm{W}=0.219$.

Figure 19. Problems Priority of Chance Event Aspect

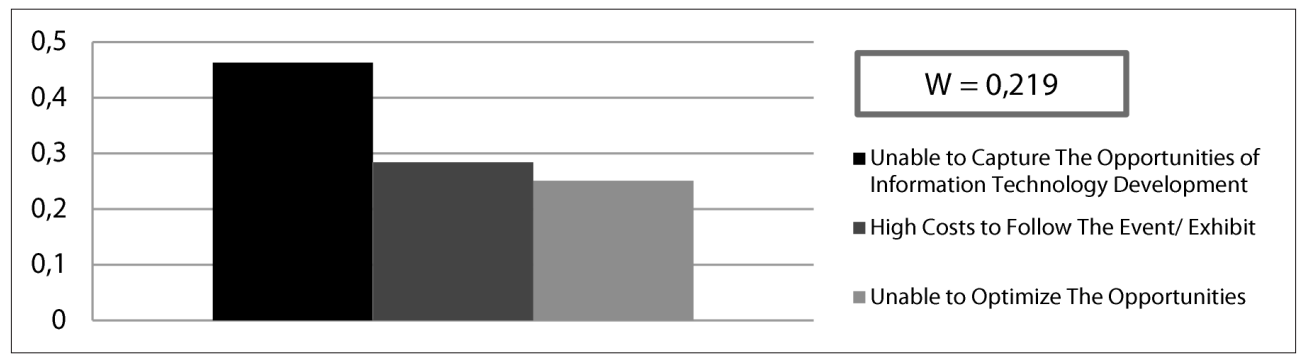

Source: ANP output, 2016

Solutions for the last aspect that can be offered to solve the problem of chance events according to respondents are promotion facilitation through information technology on the national or international's scope, grants for exhibitions and promotion cost, and education for SMEs face the global opportunities and challenges. Figure 20 shows that the solution in the aspect of chance events based on respondent's perception.

Figure 20. Solutions Priority for Aspect of Chance Event

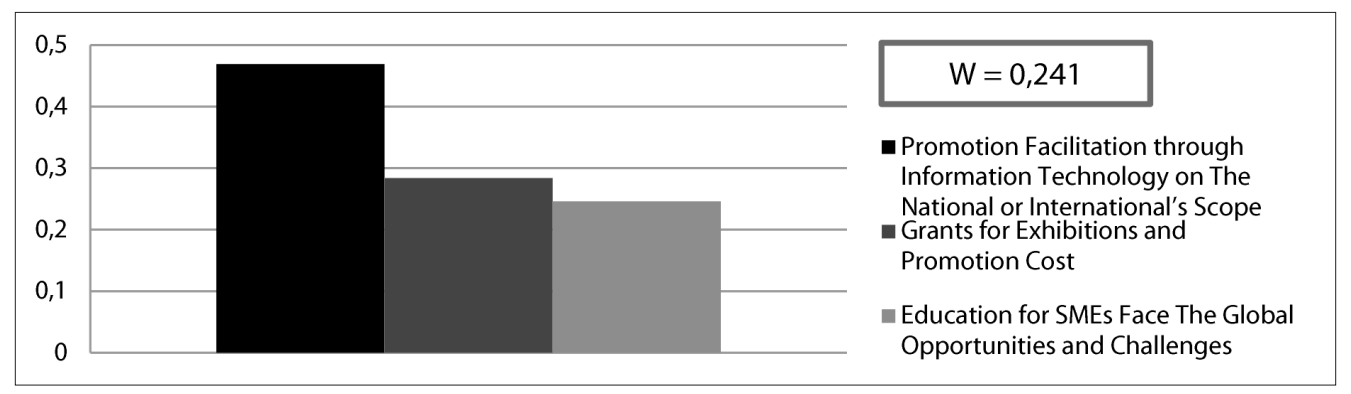

Source: ANP output, 2016

The first priority was promotion facilitation through information technology in the national or international levels. The next priority was granted for exhibitions and promotion cost and education for SMEs face the global opportunities and challenges. Solutions in the aspects of chance events had rater agreement value of $\mathrm{W}=0.241$.

Based aspects, problems, and solutions that have been developed, the final step of the 
ANP method is determining the strategic priority for strengthening the competitiveness of SMEs. The results of in-depth interviews with 24 respondents indicated that the strategy for strengthening the competitiveness of SMEs included the strategy of optimization the application of agricultural technology, strategy of management and business, strategy of vertical and horizontal integration, strategy to increase quantity and quality of products, strategy of education and workforce training, optimization of role government and related departments, entrepreneurial training for SME entrepreneurs and prospective entrepreneurs, strategy of partnerships and professional development, and strategy of developing promotion capacity. ANP method results in the priority of a strategy to strengthen the competitiveness of SMEs that be seen in Figure 21.

Figure 21. Strategy Priority of Strengthening SME's Competitiveness

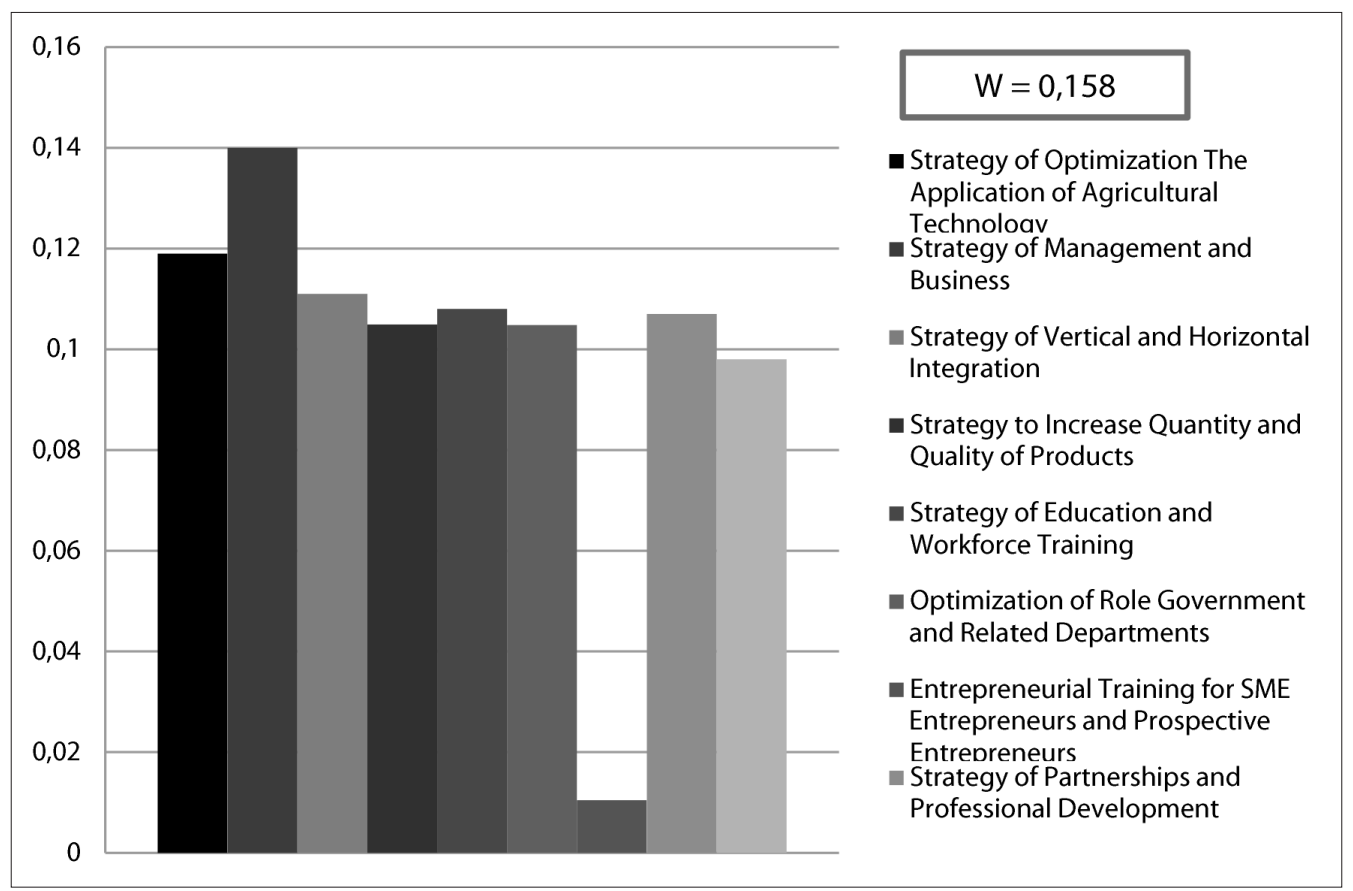

Source: ANP output, 2016

Results of the strategic priority based on 24 respondents indicated that the most important strategy to strengthen the SME's competitiveness was managerial and business strategy. The second important strategy was optimizing the application of agricultural technology. The third strategy was vertical and horizontal integration. The fourth strategy was education and manpower training. The fifth strategy was developing partnerships and professional. The sixth strategy was the improving quality and quantity of products. The seventh was optimizing the role of government and related departments. The eighth was entrepreneurial training for SME entrepreneurs and prospective entrepreneurs, and the last strategy was the increasing promotion capacity. All of this priority strategy had rater agreement value of $\mathrm{W}=0.158$. 


\section{Conclusion}

Model of strengthening SME's competitiveness in Indonesia is the integrated and sustainable program from the state level, province level, and district/ city level. The expected goal is the strengthening the competitiveness of SMEs in Indonesia that can be looked through increasing value-added and marketing range, improving institution by business modernization, increasing capacity and business protection with policy and incentive, increasing access into financing, and improving quality of human resource. Based on NineFactor model, ANP method results in the priority of aspect and strategy for strengthening SME's competitiveness. The most priority aspect to enhance SME's competitiveness is business context. The most priority strategy to enhance SME's competitiveness is the strategy of management and business.

Some recommendations based on the results of the analysis can be advisable for the government and further research. The ANP method described the Nine-Aspect that be derived from the problems, alternative solutions, and strategies. It can be used as a reference for the government to strengthen SME's competitiveness. The government should be able to anticipate problems that arise in strengthening SME's competitiveness and optimize the solutions obtained for each aspect. The government also can optimize strategic priority that is business context to make policy that supporting the strengthening SME's competitiveness. The further research is recommended to observe the economic activities with a broader scope not only SMEs. Thus the competitiveness of a region can be described more holistic.

\section{References}

Anton, S. A., Muzakan, I., Muhammad, W. F., Syamsudin, \& Sidiq, N. P. (2015). An Assesment of SME Competitiveness in Indonesia. Journal of Competitiveness. Vol. 7(2): 60-74.

Bambang. (2013). Analisis Penerapan Local Economic Development dan Dampaknya Terhadap Pertumbuhan Sektor Pertanian dan Kemiskinan Di Jawa Tengah (Analysis of Local Economic Development and Its Impact on Agricultural Sector Growth and Poverty in Central Java). (Unpublished Thesis). Semarang: Universitas Diponegoro.

Bappeda Central Java. (2011). Laporan Hasil Monitoring dan Evaluasi Program Pengembangan Ekonomi Lokal (PEL) Di Jawa Tengah Tahun 2011 (Report on Monitoring and Evalution Result of Local Economic Development Program (PEL) in Jawa Tengah 2011). Semarang : Badan Perencanaan dan Pembangunan Daerah Central Java.

Bartik. (2004). Local Economic Development Policies. In Aronson, R.J., \& Schwartz, E. (ed). Economic Development $\left(5^{\text {th }} \mathrm{ed}\right)$. Washington DC: International City/County Management Association.

Blakely, E.J. (1994). Planning Local Economic Development, Theory and Practice. (2 $\left.{ }^{\text {nd }} \mathrm{ed}\right)$. California: SAGE Publication. 
Canzanelli, G. (2001). Overview and Learned Lessons on Local Economic Development, Human Development, and Decent Work. Working papers: University. Retrieved from: http://www.ilo.org/public/english/ universitas/ download/ publi/led1.pdf.

Cho, D. (1994). A Dynamic Approach to International Competitiveness: The Case of Korea. Journal of Far Eastern Business. Vol. 1(1): 17-36.

Cho, D.S., \& Moon, H.C. (2005). National Competitiveness: Implications for Different Groups and Strategies. International Journal of Global Business and Competitiveness. Vol. 1, (1): 1-11.

Cordeiro, A.S., \& Vieira, F.D. (2012). Innovation: A Strategy That Leads to Competitiveness in SMEs. Iberoamerican Journal of Industrial Engineering. Vol. 4 (8): 146-162.

Darwanto. (2011). Membangun Daya Saing Usaha Kecil Menengah (UKM) Dalam Perekonomian Nasional (Building a Competititveness of Small and Medium Enterprise in National Economy). Jurnal Ilmu Manajemen dan Akuntansi Terapan. Vol.2 (1): 25-33

Darwanto., Hendarto, M., \& Hastarini, D. (2010). Pemetaan Usaha Kecil Menengah di Jawa Tengah (Mapping of Small Medium Enterprise in Central Java). (Unpublished Research Report). Semarang: Universitas Diponegoro.

Darwanto (2010). Pemberdayaan UMKM Melalui Strategi Permodalan dan Manajemen dengan Pembentukan Koperasi (The Empowerment of SMEs Through Capital Strategy and Management with Cooperative Establishment). Jurnal Dian Udinus. Vol.10 (3): 301-310.

Hagen, B., Zucchella, A., Cerchiello, P., \& Giovanni, N.D. (2012). International strategy and performance- Clustering strategic types of SMEs. International Business Review. Vol. 21: 369-382

Hutchinson, K., Quinn, B., \& Alexander, N. (2006). SME Retailer Internationalization: Case Study Evidence from British Retailers. International Marketing Review, Vol. 23 (1): 25-53.

Knight, G.A. (2001). Entrepreneurship and Strategy in The International SME. Journal of International Management. Vol. 7 (3): 155-171. DOI: https://doi.org/10.1016/S10754253(01)00042-4.

Kossai, M., \& Piget, P. (2014). Adoption of Information and The Communication Technology and Firm Profitability: Empirival Evidence from Tunisian SMEs. Journal of High Technology Management Research. Vol. 25: 9-20.

Kraja (Borici), Y., \& Osmani, E. (2013). Compeititve Advantage and Its Impact in Small and Medium Enterprises (SMEs) (Case of Albania). European Scientific Journal. Vol. 9(16): 76-85.

Maciej, Z., \& Natalia, P. (2016). Cooperation in Creating Innovation in Polish Small and Medium-Sized Enterprises in The Light of Empirical Studies. Journal of Competitiveness. Vol. 8(2): 42-58. DOI: https://doi.org/10.7441/joc.2016.02.04. 
Mahadalle, A., \& Kaplan, B. (2017). Entrepreneurial Characteristics and Competencies as Determinants of Corporate Performance: A Study on Small Enterprises in Mogadishu, Somalia. International Journal of Research-Granthaalayah. Vol. 5 (5): 243-254. DOI: https//doi.org/10.5281/zenodo.583915.

Manole, D.S., Nisipeanu, E., \& Decuseara, R. (2014). Study on The Competitiveness of Small and Medium-sizes Enterprises (SMEs) in Valcea Country. Journal Theoritical and Applied Economics. Vol XXI (4): 113-130.

Moon, H.C., \& Cho, D.S. (2000). National Competitiveness: A Nine-Factor Approach and Its Empirical Application. Journal of International Business And Economy. Vol. 1(1): $17-38$.

Nikraftar, T. (2016). The Competitiveness of Small and Medium Sized Enterprises of Stone Industry. Journal of Engineering Management and Competitiveness (JEMC). Vol. 6 (2): 92-98.

O'Cass, A., \&Weerawardena, J. (2009). Examining The Role of InternationalEntrepreneurship, Innovation and International Market Performance in SME Internationalization. European Journal of Marketing, Vol. 43 (11/12): 1325 - 1348.

Phinaitrup, B.A. (2011). Strengthening The Competitiveness of Small and Medium Enterprises by Using The Cluster-Based Approach: A Case Study of The Ratchaburi Orchid Cluster in Thailand. International Journal of Arts \& Sciences. Vol. 4(9): 401-412.

Patushi, S., \& Kume, V. (2014). The Development of Clusters as A Way To Increase Competitiveness Of Businesses (Case Of Milk Processing Industry In Tirana). European Scientific Journal. Vol.10 (13): 98-116.

Quartey, P. (2001). Regulation, Competition, and Small and Medium Enterprises in Developing Countries. Working Paper No. 10. Manchester: Centre on Regulation and Competition, University of Manchester.

Rodriguez-Pose, A., \& Tijmstra. S. (2005). Local Economic Development as an Alternative Approach to Economic Development in Sub-Saharan Africa. (Working Paper). London: London School of Economics. Retrieved from http://siteresources.worldbank. org/INTLED/Resources/3396501144099718914/ AltOverview.pdf. Accessed in September 7, 2012.

Sánchez, J. (2012). The Influence of Entrepreneurial Competencies on Small Firm Performance. Revista Latinoamericana de Psicologia. Vol. 44(2): 165-177.

Sudaryanto, R., \& Wijayanti, R.R. (2012). Strategi Pemberdayaan UMKM Menghadapi Pasar Bebas Asean (Empowerment Strategy of SMEs Facing ASEAN Free Market). Retrieved from: http://www.kemenkeu.go.id/sites/default/files/Strategi\%20 Pemberdayaan\%20 UMKM.pdf.

Suh, Y., \& Kim, M.S. (2014). Internationally Leading SMEs vs. Internationalized SMEs: Evidence of Success Factors From South Korea. International Business Review. Vol. 23: $115-129$. 
Tambunan, T. (2008). SMEs Development In Indonesia: Do Economic Growth And Government Support Matter?. International Journal of Asia Pacific Studies. Vol. 4(2): 111-133.

Vuković, D., Jovanović, A., \& Đukić, M. (2012). Defining Competitiveness through The Theories of New Economic Geography and Regional Economy. J. Geogr. Inst. Cvijic. Vol. 62(3): 49-64. 


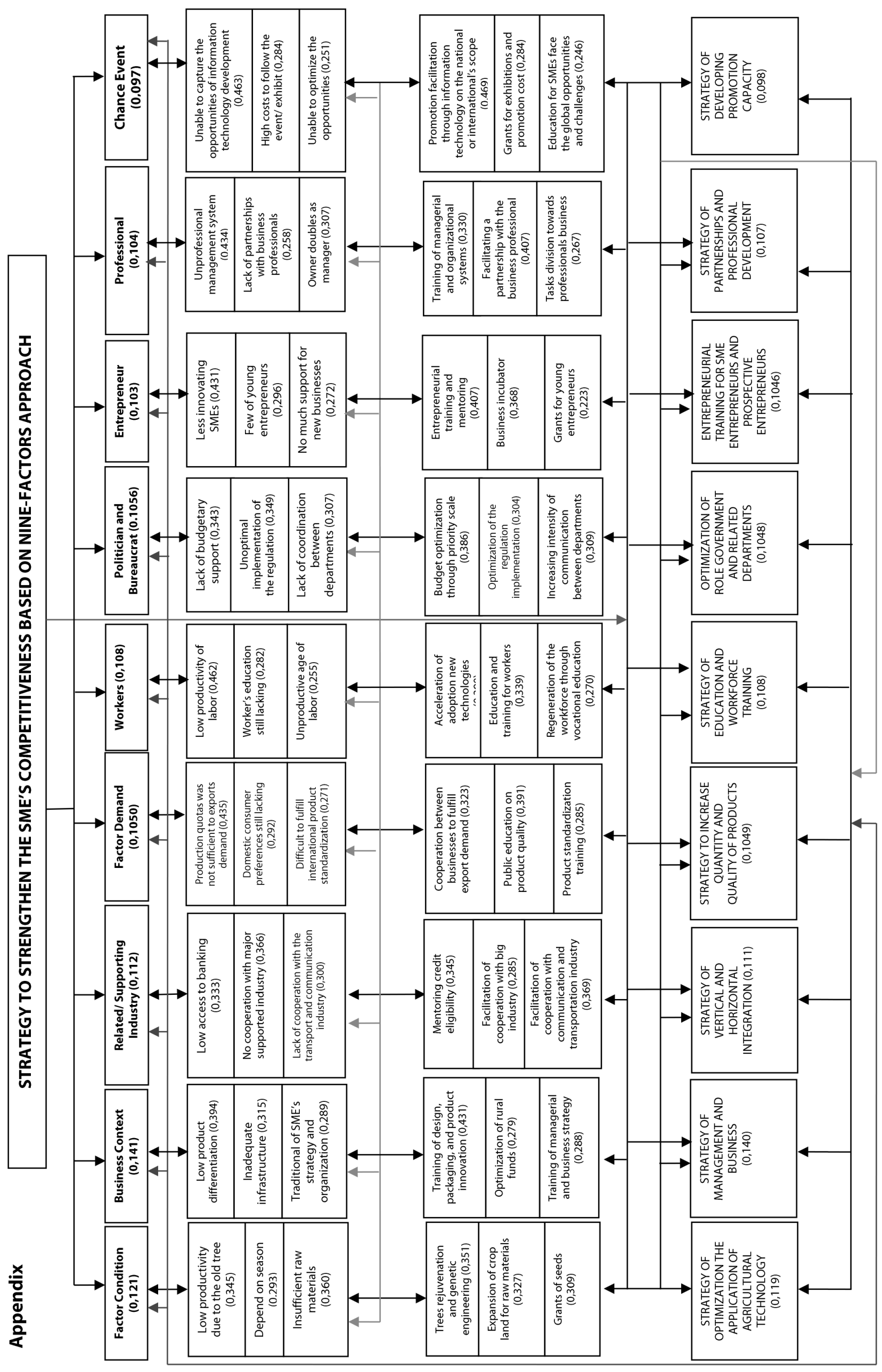

